\title{
Use of sugar cane to feed lactating dairy goats
}

\author{
[Uso da cana-de-açúcar na alimentação de cabras leiteiras em lactação] \\ A.M.D. Cabral ${ }^{1}$, F.F.R. Carvalho $^{1}$, G.C.L. Santos $^{1}$, J.C. Ferreira ${ }^{1}$, \\ M.J.M.S. Silva ${ }^{1}$, G.R.A. Santos ${ }^{2}$, G.S. Belo Júnior ${ }^{3}$, N.D. Melo ${ }^{4}$ \\ ${ }^{1}$ Universidade Federal Rural de Pernambuco/UFRPE - Recife, PE \\ ${ }^{2}$ Universidade Federal de Sergipe/UFS - Aracaju, SE \\ ${ }^{3}$ Aluno de graduação - Universidade Federal de Pernambuco/UFPE - Recife, PE \\ ${ }^{4}$ Aluna de graduação - Universidade Federal de Campina Grande/UFCG - Campina Grande, PB
}

\begin{abstract}
The aim of the present study was to assess the effects of replacing corn silage with sugarcane in the diet of lactating Saanen goats and to determine their intake and digestibility of nutrients, ingestive behavior, milk yield and composition. The experimental diets were composed of increasing levels $(0,33,66$ and $100 \%$ ) of substitution in dry matter (DM). Twelve multiparous Saanen goats, with an average body weight of $45.2 \mathrm{~kg}$, average milk yield of $3.0 \mathrm{~kg} \mathrm{day}^{-1}$, distributed in a triple latin square experimental design $(4 \times 4)$ were used. The dry matter intake $(\mathrm{DMI})$ and other nutrients were estimated through the difference between the total nutrient in the food offered and its total in the leftovers. The DMI, crude protein, neutral detergent fiber (NDF) and total digestible nutrients were not influenced, but the apparent digestibility of DM and NDF decreased. Feeding time and feeding efficiency were not influenced, the rumination and total chewing times increased, and the leisure time decreased, both linearly. Milk yield was not influenced by substitution levels, but corrected milk yield to $3.5 \%$ fat decreased. Sugar cane represents a dietary alternative for goats with medium milk yield in critical periods of forage, since it does not change the consumption of DM and milk yield, even with the apparent declining digestibility of some nutrients, influencing the ingestive behavior of the animals.
\end{abstract}

Keywords: digestibility, fiber, milk yield, ruminants

\section{RESUMO}

O objetivo do presente estudo foi avaliar os efeitos da substituição da silagem de milho por cana-deaçúcar na dieta de cabras Saanen em lactação e determinar a ingestão e a digestibilidade de nutrientes, o comportamento ingestivo, a produção e a composição do leite. As dietas experimentais foram compostas de níveis crescentes (0, 33, 66 e 100\%) de substituição na matéria seca (MS). Doze cabras Saanen multíparas, com peso corporal médio de 45,2kg, produção média de leite de 3,0kg dia ${ }^{-1}$, foram distribuídas em delineamento experimental triplo quadrado latino $(4 \times 4)$. A ingestão de matéria seca (IMS) e de outros nutrientes foi estimada por meio da diferença entre o total de nutrientes nos alimentos oferecidos e o total nas sobras. A IMS, a proteína bruta, a fibra em detergente neutro (FDN) e os nutrientes digestiveis totais não foram influenciados, mas a digestibilidade aparente da MS e da FDN diminuiu. A produção de leite não foi influenciada pelos níveis de substituição, mas a produção de leite corrigida para 3,5\% de gordura diminuiu. A cana-de-açúcar representa uma alternativa alimentar para cabras com produção média de leite em períodos críticos de forragem, pois não altera o consumo de MS e a produção de leite, mesmo diminuindo a digestibilidade aparente de alguns nutrientes e influenciando o comportamento ingestivo dos animais.

Palavras-chave: digestibilidade, fibra, produção de leite, ruminantes

Recebido em 29 de abril de 2020

Aceito em 28 de agosto de 2020

E-mail: amdcabral@gmail.com 


\section{INTRODUCTION}

For dairy goat breeding the quality of forage is of fundamental importance, as it affects the intake of animals and the apparent digestibility of food, reflecting in the production, and consequently in the commercialization of milk and its derivatives. As reported by Nazli et al. (2018), the corn plant (Zea mays) has been used in the form of silage to feed ruminants in several parts of the world, especially for its high production of dry matter, ease of harvest, suitability for fermentation in silo and high concentration of net energy.

Among Brazilian agricultural crops, sugarcane (Saccharum officinarum) ranks second place in the worldwide production ranking (FigueroaRodríguez et al., 2019), given its importance for the generation of sugar and biofuels. However, due to the need to reduce costs in animal feeding and greater economic return to the rearing system, this has been used and shown to be a nutritionally viable food alternative (Oliveira et al., 2019 Cabral et al., 2015; Worku et al., 2015; Nyakira et al., 2015).

To Leng (1988), sugarcane has some limitations in relation to its nutritional value, when used as a single food it becomes unbalanced by the low protein content and the characteristics of the fiber present in its cell wall. The structural nature of the neutral detergent fiber is able to inhibit the action of microbial enzymes in the rumen, resulting in a negative correlation between the digestibility and the intake of dry matter (Mcallister and Ribeiro et al., 2016). On the other hand, since it is processed to a reduced particle size, it results in favoring the attack of ruminal bacteria. Nocek and Russel (1988) highlighted the importance of the synchronism between a readily digestible carbohydrate source and the nitrogen available in the rumen, as essential for microbial growth and stimulating the production process. This condition directly influences the ingestive behavior of the animals due to the time spent on feeding, rumination and leisure.

Thus, the hypothesis of this work is based on the fact that the energy:nitrogen ratio of the diets through the substitution of corn silage for sugarcane to lactating goats, can favor food intake, digestibility of nutrients and consequently not affect the ingestive behavior and milk yield of goats. Hence, this study aimed to evaluate the effect of replacing corn silage with sugarcane on the intake and apparent digestibility of nutrients, the ingestive behavior, milk yield and composition of lactating Saanen goats.

\section{MATERIALS AND METHODS}

The experiment was carried out in the UFRPE in the Recife metropolitan area which, is located at $08^{\circ} 03^{\prime} 14^{\prime \prime} \mathrm{S}$ and $34^{\circ} 52^{\prime} 51^{\prime \prime} \mathrm{W}$ and has a hot and humid climate, with more than $1000 \mathrm{~mm}$ of rainfall, a mean temperature higher than $18^{\circ} \mathrm{C}$ and relative air humidity of between 79.2 and 90.7\%. The Ethics Committee of the Universidade Federal Rural de Pernambuco (UFRPE) approved this study under protocol number 23082021700/2014-84 and conducted it in accordance with ethical standards.

Based on milk yield and the order of births, the goats were arranged in a triple latin square statistical design $(4 \times 4)$ to determine the effects of different replacement levels, with corn silage replaced by sugarcane $(0,33 ; 66$ and $100 \%)$. The ingredients and chemical composition of the experimental diets are shown in Table 1 and 2 .

Table 1. Chemical composition of the ingredients of experimental diets for lactating goats

\begin{tabular}{lcccc}
\multicolumn{1}{c}{ Item $\left(\mathrm{gkg}^{-1} \mathrm{DM}\right)$} & Sugarcane & Corn silage & Corn & Soy \\
\hline Dry matter $^{\mathrm{a}}$ & 208.1 & 306.0 & 878.4 & 872.5 \\
Organic matter $^{\mathrm{b}}$ & 956.3 & 952.5 & 984.6 & 933.2 \\
Crude protein $^{\mathrm{b}}$ & 12.0 & 60.2 & 74.7 & 464.8 \\
Neutral detergent fiber $^{\mathrm{b}}$ & 501.5 & 433.3 & 111.5 & 145.2 \\
Acid detergent fiber $^{\mathrm{b}}$ & 287.0 & 215.9 & 21.8 & 64.7 \\
Mineral matter $^{\mathrm{b}}$ & 43.7 & 47.5 & 15.4 & 66.8 \\
Total Carbohydrates $^{\mathrm{b}}$ & 932.3 & 851.6 & 833.0 & 424.7 \\
Non-fibrous carbohydrates $^{\mathrm{b}}$ & 430.8 & 418.3 & 721.5 & 279.5 \\
Lignin $^{\mathrm{b}}$ & 39.7 & 41.2 & 4.3 & 6.5 \\
\hline
\end{tabular}

\footnotetext{
${ }^{\mathrm{a}} \mathrm{gkg}^{-1}$ food. ${ }^{\mathrm{b}} \mathrm{gkg}^{-1}$ in the dry matter.
} 
The calculation of the diets that exclusively contained corn silage (Table 2) were made according to the NRC (Nutrient..., 2007) in order to satisfy the demands of lactating goats with a body weight of $43 \mathrm{~kg}$, mean milk yield of

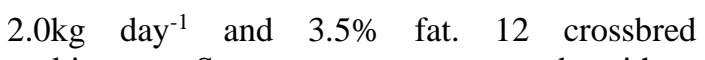
multiparous Saanen goats were used, with a mean live weight of $45.22 \pm 5.3 \mathrm{~kg}$ and $42.23 \pm$ 2.66 days of lactation at the beginning of the experiment and $2,04 \mathrm{~kg} \mathrm{day}{ }^{-1}$.

Table 2. Percentage and chemical composition of the ingredients of experimental diets

\begin{tabular}{|c|c|c|c|c|}
\hline \multirow[t]{2}{*}{ Foods $\left(\mathrm{gkg}^{-1} \mathrm{DM}\right)$} & \multicolumn{4}{|c|}{ Replacement levels (\%) } \\
\hline & 0 & 33 & 66 & 100 \\
\hline Corn silage & 506.1 & 338.5 & 172.6 & 00.0 \\
\hline Sugarcane & 00.0 & 170.1 & 342.6 & 496.9 \\
\hline Ground corn & 348.7 & 330.2 & 308.7 & 294.7 \\
\hline Soybean meal & 140.5 & 156.4 & 171.3 & 203.7 \\
\hline Mineral supplement $^{1}$ & 4.7 & 4.8 & 4.8 & 4.7 \\
\hline \multicolumn{5}{|c|}{ Chemical composition ( $\left.\mathrm{gkg}^{-1} \mathrm{DM}\right)$} \\
\hline Dry matter & 450.0 & 403.0 & 362.0 & 338.0 \\
\hline Organic matter & 957.0 & 956.0 & 956.0 & 955.0 \\
\hline Crude protein & 122.0 & 120.0 & 117.0 & 122.0 \\
\hline Ethereal extract & 53.0 & 47.0 & 42.0 & 37.0 \\
\hline Neutral detergent fiber & 279.0 & 292.0 & 306.0 & 312.0 \\
\hline Acid detergent fiber & 126.0 & 139.0 & 153.0 & 162.0 \\
\hline Mineral material & 39.0 & 39.0 & 39.0 & 40.0 \\
\hline Total carbohydrates & 781.0 & 788.0 & 796.0 & 795.0 \\
\hline Non-fibrous carbohydrates & 503.0 & 497.0 & 490.0 & 484.0 \\
\hline Lignin & 23.0 & 23.0 & 23.0 & 22.0 \\
\hline Total digestible nutrients & 775.8 & 775.9 & 673.1 & 728.1 \\
\hline
\end{tabular}

The experimental periods were 21 days, with 14 days for the animals to adapt to the experimental diets and adjust to voluntary intake, followed by seven days for data and sample collection (total of 84 days). At the beginning and at the end of each experimental period, the goats were weighed. The CO 331 variety (popularly $3 \mathrm{X}$ ) of sugarcane was used, with cuts every three days. One hour before provision, a forage machine chopped the sugarcane, with the particle size set at 2 to $5 \mathrm{~cm}$. The silo was opened to remove the corn silage and then sealed quickly to avoid a loss of silage quality. The forage was mixed with the concentrate in accordance with the treatment protocols and given to the goats twice daily (8am and $4 \mathrm{pm})$ in the form of a complete mixture.

Goats were hand milked twice a day at 06:00 a.m. and 3:00 p.m., and milk yield was recorded along the five days of data collection. The $3.5 \%$ fat corrected milk (FCM) was calculated according to Sklan et al. (1992) using the equation: $\mathrm{FCM}(\mathrm{kg}$ day -1$)=(0.4255 \times$ milk yield $)+[(16.425 \times(\%$ fat of milk/100 $) \times$ milk yield]. Milk samples were collected proportionally to the yield at each milking then analyzed for fat, protein, lactose and total solids concentration using infrared analysis (Bentley2000, Bentley instrument, Inc. Minnesota, USA). Feed efficiency (FE) was obtained from the ratio between the average 3.5\% FCM and DMI during the collection period, according to the following equation: $\mathrm{FE}(\mathrm{kg})=\mathrm{FCM}(\mathrm{kg}) \mathrm{DMI}^{-1}$.

The leftover food was weighed to adjust the daily intake, in accordance with the previous days' intake, considering $15 \%$ of that which was offered. At the start and end of each period, the goats were weighed before their morning feeding. Sampling was conducted for the equivalent of $10 \%$ of all leftovers, which were pre-dried in a forced-air ventilation oven at $60^{\circ} \mathrm{C}$ for 72 hours. The same procedure was carried out for the food and feces samples. All the samples were ground in a Willey mill (TE-625, TECNAL, SP and Brasil with a sieve of $1 \mathrm{~mm}$. Then, they were mixed to create the compound samples per animal and per period, which were 
used in the bromatological analysis. The ingestion of DMI and other nutrients were estimated based on the difference between the total nutrients in the food offered and the total in the leftovers.

The food, leftover and feces samples were sub+mitted to analysis in relation of dry matter (DM), organic matter (OM) and crude protein (CP). Then carried out according to the methods described by the AOAC (Official methods of analysis, 1990), method number 934.01 for DM, 930.05 for OM and 981.10 for CP. Whereas ether extract (EE) was analyzed by Soxhlet extraction with petroleum ether AOAC (Official methods of analysis, 1990); method number 920.39). The concentration of NDF was analyzed using a heat-stable amylase and corrected for ash, based on the procedures described by Mertens (2002), however, in this study the samples were placed in polyethylene pots with $100 \mathrm{~mL}$ of neutral detergent and autoclaved Senger et al., 2008). For the determination of acid detergent fiber (ADF) content, $100 \mathrm{~mL}$ of acid detergent was added (Van Soest and Robertson, 1985). Non-fibrous carbohydrates (NFC) were calculated according to Hall (2000) using the following equation: $\mathrm{NFC}\left(\mathrm{gkg}^{-1}\right)$ $=1000-(\% \mathrm{CP}+\% \mathrm{NDFap}+\% \mathrm{EE}+\%$ ash $)$, where NDFap is the neutral detergent fiber corrected for ash and protein. Total digestible nutrients (TDN) were determined according to Weiss (1999) using the following equation: TDN $\left(\mathrm{gk} \mathrm{g}^{-1}\right)={ }_{\mathrm{D}} \mathrm{CP}+{ }_{\mathrm{D}} \mathrm{NDF}+{ }_{\mathrm{D}} \mathrm{NFC}+\left({ }_{\mathrm{D}} \mathrm{EE} \times 2.25\right)$; where ${ }_{\mathrm{D}} \mathrm{CP}=$ digestible crude protein, ${ }_{\mathrm{D}} \mathrm{NDF}=$ digestible neutral detergent fiber, ${ }_{\mathrm{D}} \mathrm{NFC}=$ digestiblenon-fibrous carbohydrates, and ${ }_{\mathrm{D}} \mathrm{EEI}=$ digestible ether extract.

Feces samples were collected to estimate apparent digestibility, with sampling during spontaneous excretion from the second to the fourth day of the post-feeding collection period. Compound samples, classified by animal and experimental period, were formed and later placed in polyethylene containers for further analysis. To estimate the fecal dry matter production, the indigestible acid detergent fiber (iNDF) was used as an internal marker to evaluate feedstuffs, orts and feces using the method described by Valente et al. (2011).

The observations on the ingestive behavior of animals were performed using the instantaneous scanning method proposed by Martin and Bateson (1993). The goats were observed every $5 \mathrm{~min}$ for $24 \mathrm{~h}$ each day for three consecutive days, starting immediately after the morning feed, totaling $72 \mathrm{~h}$ of observation. Trained observers on a strategically placed rotating system were used. The activities recorded for each goat were rumination, feeding and idling. Total chewing time was calculated as the sum of the eating and ruminating times. A period of rumination was defined as at least 5 minutes of rumination which occurred after 5 minutes without any ruminating activity. The average number of rumination chews per bolus and the time spent chewing per ruminal bolus were recorded in two individual observations performed on three sequential days from 10:00 a.m. to $12: 00$ p.m. and 4:00 a.m. to 06:00 a.m., using a digital timer (Bürger et al., 2000).

The count was taken at every three sequential boluses in each observation interval, from the moment the ruminal bolus reached the mouth of the animal until it was swallowed. The feed and rumination efficiencies $\left(\mathrm{kg}\right.$ hour $\left.^{-1}\right)$ of $\mathrm{DM}$ and NDF were calculated by dividing the intake of each of these nutrients by the total feeding time (feed efficiency (FE)) or rumination time (rumination efficiency (RE)).

The results were submitted to analysis of variance (ANOVA) and regression equation, with the level of significance set at $5 \%$ of type I errors. Were used Statistical Analysis System (SAS) version 9.0 with linear effect and quadratic using the GLM procedure, according to the equation model: Yijkl $=\mu+\mathrm{Q} i+\mathrm{T} j+\mathrm{P}_{k}+$ $(\mathrm{A} / \mathrm{Q}) i l+\mathrm{Q} \times \mathrm{T} i j+$ eijkl. Where: Yijkl $=$ observation in goat $l$, in the period $k$, submitted to treatment $j$, in the Latin square $i$; $\mu=$ general mean, $\mathrm{Q} i=$ effect of the Latin square $i$, in which $i=1,2$ and $3 ; \mathrm{T} j=$ effect of the treatment $j, \quad$ where $j=1,2, \quad 3$ and $4 ; \mathrm{Pk}=$ effect of the experimental period $\mathrm{k}, 169$ where $\mathrm{k}=1,2,3$ and 4 ; $(\mathrm{A} / \mathrm{Q}) i l=$ effect of the animal $l$, inside the Latin square $i$, where $l=1,2$, 3 and $4 ; \mathrm{Q} \times \mathrm{T} i j=$ effect of the interaction between the Latin square $i \times$ treatment $j$; eijkl= the random error associated with each observation $i j k l$; eijkl NID (o, s2). 


\section{RESULTS}

The levels of substitution of corn silage for sugarcane did not influence the IDM, regardless of how it was expressed (Table 3), as well as for the intake of OM, CP, NFC, NDF and TDN, no effect was found $(\mathrm{P}>0.05)$ significant. There was a reduction $(\mathrm{P}=0,0001)$ in the apparent digestibility of DM and most nutrients (Table 3) with the levels of substitution of corn silage for sugarcane. The apparent digestibility coefficient of the FDA was influenced in a quadratic way $(\mathrm{P}=0,0053)$ by the levels of substitution of corn silage for sugarcane, and the substitution of $14 \%$ provided a maximum digestibility of $21.5 \%$.

Table 3. Intake and digestibility of nutrients among goats fed with sugarcane instead of silage

\begin{tabular}{|c|c|c|c|c|c|c|c|}
\hline \multirow{2}{*}{ Intake } & \multicolumn{4}{|c|}{ Replacement level (\%) } & \multirow{2}{*}{$\mathrm{CV}(\%)$} & \multicolumn{2}{|c|}{ Effect } \\
\hline & 0 & 33.3 & 66.6 & 100 & & Linear & Quadratic \\
\hline 1. $\left(\mathrm{kg} \mathrm{day}^{-1}\right)$ & 1.71 & 1.70 & 1.84 & 1.68 & 18.33 & 0.8104 & 0.8477 \\
\hline 2. $\left(\mathrm{gkg}^{-1} \mathrm{BW}\right)$ & 37.9 & 37.5 & 41.6 & 37.3 & 18.51 & 0.6643 & 0.8962 \\
\hline \multicolumn{8}{|l|}{ Nutrients $\left(\mathrm{g} \mathrm{day}^{-1}\right)$} \\
\hline \multirow[t]{2}{*}{ 3. Organic material } & 1630 & 1630 & 1760 & 100 & 18.33 & 0.8533 & 0.8811 \\
\hline & 230 & 220 & 230 & 230 & 17.03 & 0.9695 & 0.8882 \\
\hline \multirow[t]{2}{*}{ 4. Non-fiber carbohydrates } & 940 & 910 & 960 & 900 & 18.32 & 0.3210 & 0.7581 \\
\hline & 400 & 430 & 510 & 420 & 20.91 & 0.8050 & 0.9760 \\
\hline 5. Acid detergent fiber & 180 & 200 & 250 & 220 & 22.82 & 0.0763 & 0.0277 \\
\hline 6. Total digestible nutrients & 280 & 300 & 300 & 110 & 24.23 & 0.7902 & 0.6766 \\
\hline \multicolumn{8}{|c|}{ Apparent digestibility coefficients $(\%)$} \\
\hline 7. Dry matter & 79.56 & 78.41 & 71.01 & 73.30 & 4.25 & 0.0001 & 0.7088 \\
\hline 8. Crude protein & 82.00 & 81.70 & 73.13 & 79.26 & 5.28 & 0.0081 & 0.6243 \\
\hline 9. Non-fiber carbohydrates & 96.52 & 95.10 & 94.00 & 94.79 & 3.11 & 0.1136 & 0.8712 \\
\hline 10. Neutral detergent fiber & 41.15 & 45.82 & 33.19 & 31.08 & 21.17 & 0.0004 & 0.6547 \\
\hline 11. Acid detergent fiber & 30.69 & 42.53 & 29.36 & 25.77 & 29.31 & 0.0610 & 0.0053 \\
\hline \multicolumn{8}{|c|}{ Line equations } \\
\hline \multirow{3}{*}{\multicolumn{3}{|c|}{$\begin{array}{l}\text { 5. } \quad \mathrm{Y}=-114.47 \mathrm{X}^{\wedge} 2+165.31 \mathrm{X}+174.46 \\
\text { 8. } \mathrm{Y}=-4.9921 \mathrm{X}+81.506 \\
\text { 11. } \mathrm{Y}=-34.097 \mathrm{X}^{\wedge} 2+25.707 \mathrm{X}+32.464\end{array}$}} & \multirow{3}{*}{$\begin{array}{l}7 . \\
10\end{array}$} & $Y=-7$ & $316 X+79$ & 466 & \\
\hline & & & & $Y=-1$ & $37 X+44$ & & \\
\hline & & & & & & & \\
\hline
\end{tabular}

Effect significant at $5 \%$. Coefficient of variation $(\mathrm{CV})$.

Feeding time was not influenced $(\mathrm{P}=0.1110)$ by the levels of substitution of corn silage for sugar cane (Table 4), while the rumination and total chewing times increased linearly $(\mathrm{P}<0.05)$ and the leisure time decreased linearly $(\mathrm{P}=0.0001)$ from 783.6 to $576.6 \mathrm{~min} \mathrm{day}^{-1}$ as the corn silage was replaced by sugar cane. Feeding efficiency was not influenced $(\mathrm{P}=0.2999)$, but both $\mathrm{DM}$ and NDF rumination efficiency decreased linearly $(\mathrm{P}<0.05)$ as corn silage was replaced by sugarcane. Likewise, no effects were found $(\mathrm{P}=0.0051)$ for the number of boluses replenished per day ( 943.56 boluses day ${ }^{-1}$ ) and chewing time per ruminated bolus $(54.88 \mathrm{sec}$ bolus $^{-1}$ ).

Feeding Time (FT); Rumination time (RT); Idle time (IT); Total chewing time (TCT); Feeding efficiency (FE); Rumination efficiency of Dry Matter $\left(\mathrm{RE}_{\mathrm{DM}}\right)$; Rumination efficiency of Neutral detergent fiber $\left(\mathrm{RE}_{\mathrm{NDF}}\right)$; Number of ruminal boluses (NRB); Remastication Chews time per bolus (RCtb); Remastication Chews per bolus (RCb); Coefficient of variation (CV). Significant at $5 \%$. Milk yield at $2.03 \mathrm{~kg} \mathrm{day}^{-1}$ was not influenced $(\mathrm{P}=0.2019$, however corrected milk yield $\left(1.78 \mathrm{~kg} \mathrm{day}\right.$ da $\left.^{-1}\right)$ for $3.5 \%$ fat decreased linearly $(\mathrm{P}=0.0147)$. There was no significant influence $(\mathrm{P}>0.05)$ for the milk protein concentration $(2.81 \%)$ as well as for the lactose content $(4.45 \%)$, while the fat content $(2.81 \%)$ and total solids $(10.88 \%)$ decreased linearly $(\mathrm{P}=0.0049)$. In Table 5, it can be seen that diets with different levels of substitution of corn silage by sugarcane provided similar feed efficiency $(1.03 \%)(\mathrm{P}=0,3963)$. 
Table 4. Ingestive behavioral variables of dairy goats as a function of diets with different levels of replacement of corn silage by sugarcane

\begin{tabular}{|c|c|c|c|c|c|c|c|}
\hline \multirow{2}{*}{ Item } & \multicolumn{4}{|c|}{ Replacement level (\%) } & \multirow{2}{*}{$\mathrm{CV}(\%)$} & \multicolumn{2}{|c|}{ Effect } \\
\hline & 0 & 33,3 & 66.6 & 100 & & Linear & Quadratic \\
\hline 1.FT $\left(\min\right.$ day $\left.^{-1}\right)$ & 205.9 & 231.6 & 260.4 & 239.1 & 21.70 & 0.11100 & 0.2939 \\
\hline 2.RT $\left(\min\right.$ day $\left.^{-1}\right)$ & 450.4 & 560.0 & 593.3 & 624.1 & 14.31 & 0.0002 & 0.1018 \\
\hline 3.IT (min day $\left.^{-1}\right)$ & 783.6 & 648.3 & 586.2 & 576.6 & 15.16 & 0.0001 & 0.1867 \\
\hline 4.TCT $\left(\min\right.$ day $\left.^{-1}\right)$ & 656.3 & 791.6 & 853.7 & 863.3 & 12.33 & 0.0001 & 0.1818 \\
\hline 5.FE $\left(\mathrm{g} \mathrm{DM} \mathrm{min}^{-1}\right)$ & 12.8 & 10.9 & 10.5 & 10.2 & 30.33 & 0.2999 & 0.0767 \\
\hline 6.RE $\mathrm{DM}_{\mathrm{DM}}\left(\mathrm{g} \mathrm{DM} \mathrm{min}^{-1}\right)$ & 5.7 & 4.4 & 4.3 & 3.8 & 23.23 & 0.0044 & 0.3903 \\
\hline 7. $\mathrm{RE}_{\mathrm{NDF}}\left(\mathrm{g}\right.$ NDF $\mathrm{min}^{-}$ & 1.4 & 1.1 & 1.2 & 0.9 & 23.94 & 0.0017 & 0.1351 \\
\hline 8.NRB $\left(n^{\circ}\right.$ day $\left.^{-1}\right)$ & 796.32 & 879.84 & 930.24 & 1167.84 & 57.42 & 0.62533 & 0.1624 \\
\hline 9.RCtb ( $\mathrm{sec}$ bolus $\left.{ }^{-1}\right)$ & 50.2 & 56.7 & 56.9 & 55.7 & 21.23 & 0.5759 & 0.5366 \\
\hline 10.RCb (bolus) day ${ }^{-1}$ ) & 36688 & 49389 & 49578 & 56148 & 23.72 & 0.0051 & 0.1999 \\
\hline \multicolumn{8}{|c|}{ Line equations } \\
\hline \multicolumn{5}{|c|}{ 2. $Y=166.19 X+474.27$} & \multicolumn{3}{|c|}{ 3. $Y=-204.58 X+750.45$} \\
\hline \multicolumn{5}{|c|}{ 4. $Y=204.58 X+689.45$} & \multicolumn{3}{|c|}{$6 . \mathrm{Y}=-1.7395 \mathrm{X}+5.4154$} \\
\hline \multicolumn{5}{|c|}{ 7. $Y=-0.4211 X+1.3595$} & \multicolumn{3}{|c|}{ 10. $Y=17577 X+39206$} \\
\hline
\end{tabular}

Table 5. Milk yield (MY), milk corrected for fat (MCF), milk composition and feed efficiency of Saanen goats receiving sugarcane instead of corn silage variables

\begin{tabular}{|c|c|c|c|c|c|c|c|}
\hline & \multicolumn{4}{|c|}{ Replacement levels (\%) } & \multirow{2}{*}{$\mathrm{CV}(\%)$} & \multicolumn{2}{|c|}{ Effect } \\
\hline & 0 & 33.3 & 66.6 & 100 & & Linear & Quadratic \\
\hline 1. MY (Kg day ${ }^{-}$ & 2030 & 2090 & 2150 & 1860 & 20.0 & 0.2019 & 0.8255 \\
\hline 2. $\mathrm{MCF}(\mathrm{Kg}$ & 1900 & 1970 & 1770 & 1490 & 17.0 & 0.0325 & 0.5525 \\
\hline \multicolumn{8}{|c|}{ Milk composition (\%) } \\
\hline 3. Fat & 2.92 & 3.04 & 2.62 & 2.68 & 9.73 & 0.0147 & 0.8175 \\
\hline 4. Protein & 2.56 & 2.61 & 2.54 & 2.53 & 3.82 & 0.3189 & 0.8081 \\
\hline 5. Lactose & 4.46 & 4.46 & 4.45 & 4.44 & 1.84 & 0.8050 & 0.6085 \\
\hline 6. S. total & 10.98 & 11.17 & 10.68 & 10.70 & 2.8 & 0.0049 & 0.3142 \\
\hline 7. *FE & 1.11 & 1.16 & 0.96 & 0.89 & 32.5 & 0.3963 & 0.2305 \\
\hline \multicolumn{8}{|c|}{ Line equations } \\
\hline \multicolumn{5}{|c|}{$\begin{array}{l}\text { 2. } Y=-430.81 X+1996.8 \\
\text { 6. } Y=-0.3991 X+11.081\end{array}$} & \multicolumn{3}{|c|}{ 3. $Y=-0.3417 X+2.985$} \\
\hline
\end{tabular}

*(MYKgkg $\left.{ }^{-1} \mathrm{DM}\right)$; Significant (5\%). Coefficient of variation (CV).

\section{DISCUSSION}

The lack of influence of the treatments for the results in the IDM (Table 3 ) is an indication that the energy availability of the diets provided a good use of nutrients by the goats. This may be associated with the processing of roughage in the forage machine, which reduced the size of its particles and favored the attack of ruminal bacteria, regardless of the treatment, since the diets were supplied in the form of a complete mixture, and as the roughage was moist, this possibly facilitated the junction of food and its ingestion, making animal selection difficult. Andrade et al. (2016) also found that there was no reduction in the IDM of the animals, working with dairy cows fed with corn silage, fresh sugar cane and ensiled sugar cane in three different ways.

Goat's intake of NDF for all treatments was very close, perhaps caused by the associative effect of food. The average intake of $44 \mathrm{~g}$ ( $\mathrm{kg}$ day) ${ }^{-1}$ possibly occurred on account of the proximity in the percentage of this nutrient between diets. Due to the fact that there are still no established values for the indication of the NDF content for the diet of goats that can ensure the ideal IDM, until now the recommendation referring to the bovine species has been based, which according to the NRC (Nutrient..., 2001) should be on average $1.2 \pm 0.1 \%$ of the animal's body weight. For this study, the average intake of $0.97 \%$ of the goats' body weight was observed. This is 
consistent with a previous study by Cabral et al. (2008), who found an average IDM of $1.13 \%$ of body weight in Saanen goats fed different levels of substitution of tifton hay for sugar cane.

The proximity of NDF intake in all treatments probably occurred because of the stimulation of the activity of ruminal microorganisms to the digestion of this fibrous portion of the cell wall, with no competition between cellulolytic and non-cellulolytic bacteria, controlled by the energy intake of the diets and responsible for the efficiency of milk intake and milk yield with an average of $2.03 \mathrm{~kg} \mathrm{day}^{-1}$, they were able to adjust their production to the intake of NDT. The recommendation made by the NRC (Nutrient..., 2007 ) is $1.11 \mathrm{~kg} \mathrm{day}^{-1}$ of TDN for goats with an average milk yield of $1.88 \mathrm{~kg} \mathrm{day}{ }^{-1}$, with the animals fed exclusively with sugarcane, presenting a value of $1.11 \mathrm{~kg} \mathrm{day}^{-1}$, exactly the same as this recommendation, for the goats of the other treatments, intake was higher.

Although the IDM was not influenced, the compromise in ADF intake of diets with higher levels of sugarcane is related to the composition of its cell wall, as it has ester-like bonds between the sugars present in the hemicellulose. For Van Soest (1994), lignin is presented as a limiting factor for fiber degradation, due to the barrier formed making it difficult for microbial adhesion and colonization to break complex bonds. Consequently, the effect of physical replenishment to the rumen environment is highlighted, caused by the indigestible fraction resulting in a reduction in the apparent digestibility of DM, NDF and ADF of the diets with the replacement of sugar cane (Table 3), considering that the lignin-cellulose complex and the crystallinity of this cellulose hinder digestion, characterizing the proportion of indigestible fiber present in the cell wall of sugarcane, which has been evidenced by some authors who have worked with sugarcane in food of ruminants, justifying the low IDM and apparent NDF digestibility coefficient (Cabral et al., 2015, Souza et al., 2017).

Due to the inherent characteristics of fibers structure that make up the cell wall of sugarcane, the lack of influence on the apparent digestibility of CNF for all diets may be associated with the fact that as the levels of inclusion concerning sugar cane increased in the diets, the animals tried to ingest the less fibrous fractions of the food. For goats that received the diet with $100 \%$ substitution, the amount of long fibers in the diet allowed for the necessary physical effectiveness to maintain ruminal functions, and consequently this component was able to promote chewing activity. Probably the rate of passage of sugar cane diets was slower, but during this path, factors such as food quality, particle size and density were able to influence when according to the NRC (Nutrient..., 2001), more digestible and high energy diets allow metabolic regulation in animal intake, and this remained similar among goats.

It is possible that the aggregation between the ingredients of the diets contributed to the similarity between the feeding time (Table 4) of the goats for the diets in all treatments, mainly because the IDM has not been influenced and the diets were offered as a complete mixture, making selection difficult by the goats. Regardless of the diet, the highest feeding time occurred right after food was offered. The feeding time was not a limiting factor for the IDM, since all animals consumed an average of $1.11 \mathrm{~kg}$ day $^{-1}$ of TDN enough to meet their nutritional requirements, according to the recommendations of the NRC (Nutrient..., 2007) that recommends this value for the intake of TDN.

According to the fact that sugarcane contains parts composed of knots and husks, this material becomes more resistant to degradation. As a result, the goats that received diets with the highest levels of corn silage substitution ruminated more to guarantee the reduction in the size of the particles, allowing a greater attack by the microorganisms and making better use of its nutrients, because according to Mertens (1997), the size of the particles in the diet influences rumination.

Sugarcane has more NDF that is physically effective than corn silage, in favor of cellulose and hemicellulose, which are the main constituents of the cell wall, compacted in crustlike arrangements with lignin, resulting in greater need for remastigation to cause the rupture of the molecules of these structures and allow the access of cellulolytic bacteria. It is also important to consider the expression of the fiber effective in meeting the minimum requirement of NDF and its relationship with non-fibrous 
carbohydrates, capable of influencing the percentage of fat in milk. Possibly the effectiveness of the NDF ensured the masticatory activity and ideal conditions of the rumen environment, allowing larger particles to remain in the superficial portion considering the processing of sugar cane in a forage machine that implies distinct particles, fine or coarse, and different capacities to stimulate chewing activity.

In accordance with França et al. (2009) the rumination time seems to have a low variation in diets rich in grains, reaching a maximum of

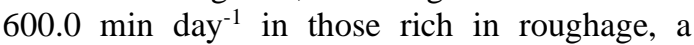
value within the maximum described by this author was found in this research, with an average of $593.3 \mathrm{~min}$ day $^{-1}$ for rumination time (Table 4 ) with $66.6 \%$ replacement of corn silage by sugarcane, although the level of $100 \%$ replacement was slightly above, with $624.1 \mathrm{~min}$ day $^{-1}$. Yet the idle time decreased from 783.6 to $576.6 \mathrm{~min}^{-1 a y^{-1}}$ as corn silage was replaced by sugar cane, since the activities of feeding, rumination and leisure are distributed during the day. Total chewing time is the sum of feeding time and rumination time.

The similarity in the feeding efficiency can be justified by both the IDM and the feeding time that did not vary between diets, despite of the fact that the fibrous portion of the cell wall of corn silage is more easily degraded than the sugar cane cell wall. The feeding efficiency proved to be a parameter that indicates that sugar cane can be used in the feeding of goats in up to $100 \%$ substitution without causing a decrease in the time that the animals spend feeding, because regardless of the roughage contained in the diet, the feeding time spent was the same.

The levels of NDF among the diets, although they were very close, the decrease in rumination efficiency DM for goats receiving diets with higher levels of substitution of corn silage for sugarcane, possibly occurred due to the very structure of the indigestible fraction of the NDF of the sugar cane, so the animals were able to remastigate less of this fraction per minute, consequently the rumination time increased for these animals in an attempt to better enjoy the food. As a general average of treatments, rumination efficiency NDF was obtained in the order of $1.15 \mathrm{gNDF} \mathrm{min}^{-1}$, whereas for the diet in which sugarcane had a total replacement of corn silage, with value $0.9 \mathrm{gNDF} \mathrm{min}^{-1}$.

In compliance with Furlan et al. (2006), per day, about 360 to 790 boluses are ruminated, with 40 to 70 chewing movements from 45 to 60 seconds occurring, the average number of ruminal boluses obtained in this study (Table 4) is right above of those observed by the author, with 943.56 boluses day $^{-1}$, considering that the fiber from the forage is responsible for the changes that occur in the feeding and rumination processes. The remastication took an average of $54.88 \mathrm{sec}$ boluses $^{-1}$ and was not influenced by the levels of substitution of corn silage for sugarcane, possibly due to the similarity between the diets, both on the particle size and chemical composition, in each bolus regurgitated by the animals, there was probably more bulk to be crushed, resulting in a greater remastication chews of food.

Oliveira et al. (2019) evaluated the feeding behavior of sheep with the inclusion of 7, 14 and $21 \%$ detoxified castor bran in diets with sugar cane silage, observed that there was an increase in the IDM considering the NBR of 907.18, which is very close to that observed in this study with an average of 943.56 but that did not imply a reduction in the IDM and milk yield. So, it can be inferred that sugar cane is a food alternative for goats.

The mean milk yield value of $2.03 \mathrm{~kg}$ day $^{-1}$ (Table 5) suggests that the ingestion of DM was one of the determining factors, since it is responsible for the animals' nutrient intake, particularly energy and protein. Results very close to this research were found by Gentil et al. (2007), who worked with Saanen goats fed with fresh and ensiled sugar cane, observed the best results for milk production $(2.07 \mathrm{~kg} /$ day) for animals fed with fresh sugar cane. European goat breeds, such as the Saanen, are known for their greater milk yield capabilities, while goats from tropical regions tend to produce less milk (Lees et al., 2019), mainly due to heat stress. Novais et al. (2015) points out the need of using regional resources available that can be inserted into the feed ruminants, making feed less costly. Therefore, the sugar cane result in one of these alternatives, and in the present study, the mean milk yield was of $2.03 \mathrm{~kg}$ milk day ${ }^{-1}$, regardless of the diet offered. 
Modest alterations of protein concentration in milk are obtained through nutrition, given that the diets were iso-protein, it is possible that there was an adequate balance of amino acids directed to the mammary gland, promoted by the rate of protein fermentation in the rumen. Cabral et al. (2008) analyzed Saanen goats that were fed with sugarcane instead of Tifton hay and obtained a protein rate of $2.68 \%$ in milk, which is higher than the mean value recorded in the present study $(2.56 \%)$. This difference could be due to the mean levels of crude protein in these studies: 19.32 and $12 ., 03 \%$, respectively.

There was a reduction of $8.22 \%$ in the level of fat in the milk of goats, when comparing those that received corn silage as forage and those that received sugarcane. One possible explanation for this decrease could be the nature of the carbohydrates found in the diets, given that carbohydrates exert a direct influence on the quantity and proportion of fatty acids produced in the rumen, particularly propionate and acetate, which the latter is necessary for the synthesis of milk fat. When this acid is found in lower quantities, the level of fat in the milk is reduced. For cattle, the NRC (Nutrient..., 2001) has recommended that the ratio between NDF and NFC should be at least 25 to $33 \%$ of the NDF and at most 36 to $44 \%$ of the NFC, in order to avoid decreases in milk fat.

There are still no reference values available for goats and as such, the values for cattle can be used as a basis. In the present study, the mean values for NDF and NFC were 297.3 and $493,5 \mathrm{gkg}-1$, respectively, which are within the boundaries of these recommendations. On the other hand, as well as the effectiveness of NDF, the type of CNF also influences the fat content of milk, and in this case, corn silage rich in moist grains probably helped in the digestion rate of starch and contributed to the depression of milk fat.

The average level of lactose $4.45 \%$ among the treatments is correlated with the energetic availability provided by the diets, which remained close to $73.75 \%$. A difference of only $7.81 \%$ was recorded between the highest and lowest levels of replacement. The values used were sufficient to ensure the supply of glucose to the mammary gland, without endangering lactose synthesis. The total solids content is subject to variation, as it corresponds to the sum of the levels of fat, protein, lactose as well as vitamins and minerals present in milk. The equivalent of $2.55 \%$ reduction can be attributed to the decrease in the fat content of milk. A level of $10.70 \%$ of total solids was recorded for the treatment that only involved sugar cane, as opposed to $10.98 \%$ for the treatment that only involved corn silage, with a minimum reduction of 0.0028 for each percentage unit of sugarcane. The mean total solids in the milk for all treatments was $10.88 \%$.

The similarities in feed efficiency are justified by the behavior of the DMI and milk yield, given that there is a direct correlation between these two parameters. Proportionally, the goats were capable of producing the same quantity of milk for each kilogram of dry matter ingested, which was sufficient for the animal's maintenance and production, once the milk yield was maintained without influence, indicating that the nutritional value of sugarcane is similar to corn silage.

\section{CONCLUSION}

Sugar cane can replace corn silage in the feeding of medium milk yield goats as exclusive roughage, without altering food intake and milk yield, but compromising the apparent digestibility of diets and the ingestive behavior of dairy goats. Sugar cane can be used as a single roughage for lactating goats with less nutritional requirements.

\section{REFERENCES}

ANDRADE, F.L.; RODRIGUES, J.P.P.; DETMANN, E. et al. Nutritional and productive performance of dairy cows fed corn silage or sugarcane silage with or without additives. Trop. Anim. Health Prod., v.48, p.747-753, 2016.

BÜRGER, P.J.; PEREIRA, J.C.; QUEIROZ, A.C. et al. Comportamento ingestivo em bezerros holandeses alimentados com dietas contendo diferentes níveis de concentrado. Rev. Bras. Zootec., v.29, p.236-242, 2000.

CABRAL, A.M.D.; BATISTA, A.M.V.; CARVALHO, F.F.R. et al. Cana-de-açúcar em substituição ao feno de capim-tifton 85 em rações para cabras Saanen. Arq. Bras. Med. Vet. Zootec., v.67, p.198-204, 2015. 
CABRAL, A.M.D.; BATISTA, Â.M.V.; MUSTAFA, A. et al. Performance of dairy goats fed whole sugarcane. Trop. Anim. Health Prod., v.41, p.279-283, 2008.

FIGUEROA-RODRÍGUEZ， K.A.; HERNÁNDEZROSAS, F. FIGUEROA-SANDOVAL, B. et al. What Has Been the Focus of Sugarcane Research? A Bibliometric Overview, Int. J. Environ. Res. Public. Health., v.16, p.3326, 2019.

FRANÇA, S.L.; GONZAGA NETO, S.; PIMENTA FILHO, E.C. et al. Comportamento ingestivo de ovelhas Morada Nova no terço final de gestação com níveis de energia metabolizável na dieta. Rev. Bras. Saúde Prod. Anim., v.10, p.73-84, 2009.

FURLAN, R.L.; MACARI, M.; FARIA FILHO, D.E. Anatomia e fisiologia do trato gastrintestinal. In: BERCHIELLI, T.T.; PIRES, A.V.; OLIVEIRA, S.G. (Ed.). Nutrição de ruminantes. FUNEP, Jaboticabal. 2006. p. 403421.

GENTIL, R.S.; SUSIN, I.; NUSSIO, L.G. et al. Milk composition and milk yield of goats sugar cane silage. In: INTERNATIONAL SYMPOSIUM ON THE CHALLENGE TO SHEEP AND GOATS MILK SECTORES, 2007, Alghero Proceedings... Alghero: [s.n.], 2007. p. 138. Abstracts.

HALL, M.B. Calculation of non-structural carbohydrate content of feeds that contain nonprotein nitrogen. Florida: University of Florida P.A-25. 2000. (Bulletin 339).

LEES, A.M.; ANDREA V.S.; WALLAGE, L. et al. The impact of heat load on cattle. Anim. Rev., v.9, p.322, 2019.

LENG, R.A. 1988. Limitacion metabolicas en la utilización de la cana y sus derivados para el crescimento e producción de leche en ruminantes. In: Sistemas Intensivos para Producción Animal y Energia Renovable con Recursos Tropicales. Cali, Colombia., 1988.

MARTIN, P.; BATESON, P. Measuring behavior: an introductory guide. New York: Cambridge University Press, 1993. 222p.
MCALLISTER, T.A.; RIBEIRO, G. Microbial strategies in the ruminal digestion of starch. Conference Paper, 2016. Available in: https://www.researchgate.net/publication/308400 390_Microbial_strategies_in_the_ruminal_digest ion_of_starch/citation/download. Acessed in: 2 Apr. 2020.

MERTENS, D.R. Creating a system for meeting the fiber requeriments of dairy cows. J. Dairy Sci., v.80, p.1463-1469, 1997.

MERTENS, D.R. Gravimetric determination of amylase treated neutral detergente fiber in feeds with refluxing in beaker or crucibles: collaborative study. J. AOAC Int., v.85, p.12171240, 2002.

NAZLI M.; HALIM R.; ABDULLAH A. et al. Potential of four corn varieties at different harvest stages for silage production in Malaysia Asian-Australa. J. Anim. Sci., v.32, p.224-232, 2018.

NOCEK, J.E.; RUSSELL, J.B. Protein and energy as an integrated system. Relationship of ruminal protein and carbohydrate availability to microbial synthesis and milk production. $J$. Dairy Sci., v.71, p.2070-2107, 1988.

NOVAIS, D.L.; LEITE, L.C.; EIRAS, C.E. et al. Desempenho de cabras em lactação alimentadas com dietas com concentrado a base de feno da parte aérea da mandioca. Arch. Zootec., v.64, p.311-315, 2015.

NUTRIENT requirements of dairy cattle. 7.ed. Washington: National Research Council, 2001. $381 \mathrm{p}$.

NUTRIENT requirements of small ruminants: sheep, goats, cervids and new words camelids. Washington: National Academy Press, 2007. 384 p.

NYAKIRA, B.S.; TUITOEK J.K.; ONJORO P.A. et al. Determination of the nutritive value of sugar cane tops, mulberry leaves (M. Alba) and Calliandra (C. Calothyrsus) as feed suplements for goats in Kenya. J. Anim. Sci. Adv., v.5, p.1225-1233, 2015 .

OFFICIAL methods of analysis, 15.ed. Arlington: AOAC International, 1990. 
OLIVEIRA, A.C.; GARCIA, R.; ALMEIDA, V.V.S. et al. Feeding behavior of sheep fed sugarcane silage enriched with detoxified castor bean meal. Acta Sci. Anim. Sci., v.41, p.e.43848, 2019.

SENGER, C.C.D.; KOZLOSKI, G.V.; SANCHEZ, L.M.B. et al. Evaluation of autoclave procedures for fibre analysis in forage and concentrate feedstuffs. Anim. Feed Sci. Technol., v.146, p.169-174, 2008.

SKLAN, D.; ASHKENAZI, R.; BRAUN, A. et al. Fatty acids, calcium soaps of fatty acids and cottonseeds fed to high yielding cows. J. Dairy Sci., v.75, p.2463-2472, 1992.

SOUZA, J.M.; SOUSA, D.O.; MESQUITA, B.S. et al. Effect of sugarcane fiber digestibility, conservation method and concentrate level on the ruminal ecosystem of beef cattle. AMB Express, v.7, p.1-9, 2017.
VALENTE, T.N.; DETMANN, E.; VALADARES FILHO, S.C. et al. Situ estimation of indigestible compounds contents in cattle feed and feces using bags made from different textiles. Rev. Bras. Zootec., v.40, p.66675, 2011.

VAN SOEST, P.J. Nutritional ecology of the ruminant. 2.ed. New York: Cornell University Press, 1994. 476p.

VAN SOEST, P.J.; ROBERTSON, J.B. Analysis of forages and fibrous foods Ithaca. New York Cornell University, 1985.

WORKU, A.; GETACHEW, A.; MENGISTU, U. et al. Effect of different levels of dried sugar cane tops inclusion on the performance of washera sheep fed basal diet of grass hay, Ethiopia. Adv. Dairy Res., v.3, p.1-5, 2015. 